Викладацька діяльність С.П. Людкевича стала вагомим внеском у становленні національної педагогічної школи. Композитора турбує питання навчання музичного мистецтва в загальноосвітній школі, викладання музично-теоретичних предметів у спеціальних навчальних закладах. Для педагогічних принципів С. Людкевича характерне прагнення виховати справжнього професіонала і водночас громадянинапатріота.

Станіславу Людкевичу завжди була близькою концепція правди в житті і мистецтві. Педагогічне кредо композитора: «Музика і пісня як була, так і буде одним із головних чинників нашої культури». Тому спадщина композитора-педагога, Станіслава Людкевича, не втрачає своєї педагогічної цінності і сьогодні.

\title{
Література:
}

1. Антонович М. Станіслав Людкевич: композитор, музикознавець. Рим, 1980. 161 с.

2. Барвінський В. Митець великого обдарування // Мистецтво. 1958. № 4. C. 26-28.

3. Бабюк Л. Музично-педагогічна діяльність С. П. Людкевича // Творчість С.П. Людкевича. Збірник статтей. Київ, 1979. С. 47-51.

DOI https://doi.org/10.30525/978-9934-26-004-9-127

\section{ОМЕЛЯН НИЖАНКІВСЬКИЙ В АРХІВНИХ ДОКУМЕНТАХ ФОНДІВ СТРИЙСЬКОГО КРАЕЗНАВЧОГО МУЗЕЮ «ВЕРХОВИНА»}

\author{
Молчко У. Б. \\ доцент кафедри музикознавства та фортепіано \\ Навчально-наукового інституту музичного мистецтва \\ Дрогобицького державного педагогічного університету \\ імені Івана Франка \\ м. Дрогобич, Львівська область, Украӥна
}

Розвиток сучасної національної культури сьогодні невіддільний від вивчення творчих надбань митців, які в силу суспільно-історичних обставин початку XX століття змушені були емігрувати, покинути рідну землю. 3 цього приводу професор Ганна Карась наголошує, що «музична культура українців діаспори, як інтегральна частина загально- 
українського музичного процесу, після довгих років ігнорування потребує вивчення, систематизації, критичного аналізу з боку вчених, митців, діячів культури» [5, с. 10]. Сьогодні до нас повертаються численні приватні збірки українських митців, які своєю творчою працею сприяли розбудові світової культури. Архіви Модеста Менцинського, Мирослава Скала-Старицького, Йосипа Гошуляка, Осипа Залеського, Зиновія Лиська, Андрія Гнатишина, Василя Безкоровайного, Ярослава Барнича, Остапа Бобикевича, Мирослава Антоновича, Ігоря Соневицького, Богдана Весоловського, Остапа Пицка, Любки Колесси, Софії Дністрянської, Антона Рудницького, Марії Сокіл-Рудницької, Свгена Цегельського, Володимира Луціва та інших проливають світло на процеси становлення і розвитку українського мистецтва.

25 вересня 2019 року невістка українського композитора Нестора Нижанківського, Зоя Лісовська-Нижанківська передала архів відомого піаніста, педагога, композитора, музиколога Омеляна Нижанківського Стрийському краєзнавчому музею «Верховина».

Омелян Нижанківський належить до яскравих представників музичного роду Нижанківських. Варто згадати імена органіста собору св. Марії в Римі, а згодом в Кракові Андрія Нижанківського (1590 (92?)1645); диригента, композитора, культурно-освітнього діяча о. Остапа Нижанківського (1863-1919); його братів, хорових диригентів Володимира і Петра; корифея української музики, композитора, піаніста, педагога, музичного критика, громадсько-мистецького діяча Нестора Нижанківського (1893-1940); музичного критика, письменницю Меланію Нижанківську; їх сина, соліста Женевської опери, співака-баритона Олега Нижанківського (1924-2003). Професор Ганна Карась зазначає, що «у Швейцарії мешкали два музиканти з давнього роду Нижанківських композитор, піаніст, органіст і педагог (професор музики) Омелян та співак-баритон Женевської опери Олег» [5, с. 110].

Короткі відомості про творчі здобутки Омеляна Нижанківського стисло подані в Малій українській музичній енциклопедії [7, с. 80], в історико-критичному огляді Антіна Рудницького [8, с. 289], у спогадах Мирослава Антоновича [1, с. 247], в нарисі Юрія Булки [2, с. 12]. У 2013 році вийшла друком стаття Уляни Граб [3, с. 67-70], у якій представлені життєві віхи та лист митця до Мирослава Антоновича.

Постать Омеляна Нижанківського $є$ маловідомою в Україні. На сьогоднішній час нам відомо, що він $є$ сином рідного брата о. Остапа Нижанківського, о. Петра Нижанківського. Мати, Северина Івасик, була уродженкою м. Дрогобича [6]. В сім'ї зростало троє дітей: Мирон, Омелян, Зеновій. Омелян народився 20 серпня 1895 році в Рогатині, де батько мав парафію. Музичні здібності проявилися в шестилітньому віці. 222 
Початкову народну школу Омелян закінчив у 1904 році у м. Золочеві. Далі навчався у Стрийській та Дрогобицькій гімназіях (1904-1912рр.). Один рік студіював право в Ягелонському університеті в Кракові. Музичну освіту здобув у Музичній академії Відня. Тут він навчався в Еміля Зауера, учня Ференца Ліста. В середині 1914 року був покликаний до австрійського війська. 31921 року проходить навчання у Вищій торговельній школі у Відні, паралельно продовжуючи навчатися музиці у Віденській музичній академій. У 1922 році залишає навчання і два роки працює книговодом у канцелярії нафтового промислу в Дрогобичі, щоб допомогти братові закінчити медичну освіту.

З 1924 по 1928 роки О. Нижанківський працює у філії Лондонської консерваторії в Каїрі у Єгипті. Але хвороба (туберкульоз кісток рук і ніг) прогресувала і у 1928 році митець переїжджає до Швейцарії. Тут він викладав у консерваторії м. Берна. У 1947 році О. Нижанківський вступає до Фрибургської консерваторії і за один рік одержує музичнопедагогічний диплом 3 найвищою оцінкою. Одночасно займається науковою діяльністю в Інституті музикології при Фрибургському університеті в професора Франца Бренна, що дало можливість отримати диплом доктора музикології в Українському Вільному Університеті в Мюнхені. Саме тут він 6 серпня 1951 року захистив дисертацію на тему «Die Historisch-systematische aufschichtung des Ukrainischen Volkslides (Grundriss)», яка присвячена історично-систематичному нашаруванню української народної пісні. Цій науковій праці О. Нижанківського професори 3. Кузеля та В. Ріцлєр дали високу оцінку. Характеризуючи здобутки відомих музикознавців Свропи, Антін Рудницький відзначає вагомий науковий доробок доктора Омеляна Нижанківського.

«Музична культура українців діаспори після Другої світової війни збагатилася значними інтелектуальними та мистецькими силами, вона сягає вищого рівня майстерності та професійної» [5, с. 123], - пише Ганна Карась. Серед видатних українських музикознавців, до яких належать Василь Витвицький, Осип Залеський, Антін Рудницький, Свген Цегельський, Роман Придаткевич, Ігор Соневицький, Зиновій Лисько, Аристид Вирста, Мирослав Антонович, Павло Маценко, Стефанія Туркевич, вирізняється постать Омеляна Нижанківського.

У 1960 році митець створює приватний музичний учбовий заклад в м. Ляйсені, продовжує традиції європейської фортепіанної школи. Антін Рудницький у праці «Українська музика» відзначає, що О. Нижанківський є «дуже цінний і поважний музика-піяніст» [8, с. 289]. Він також працював органістом, створив три Служби Божі, $є$ автором мелодії гимну ОУН «Зродились ми великої години» на слова Олеся Бабія, «Розкрийте зіниці» на вірші Олега Ольжича.

Відійшов у засвіти у 1973 році. 
Архів Омеляна Нижанківського знаходиться сьогодні на стадії опрацювання. Першу групу матеріалів становлять особисті документи Омеляна Нижанківського: паспорт О. Нижанківського, залікова книжка його як студента Ягелонського унверситету в Кракові за 1913 рік 3 оцінками, студентське посвідчення та диплом УВУ в Мюнхені, диплом про закінчення музичної консерваторії у Фрибургзі (Швецарія), довідка про доктора в університеті Фрибургзі, документ родоводу Нижанківських, медична книжка, фотоальбом, касетка 3 нагородами $\mathrm{i}$ значками, два блокноти 3 приватними адресами, картка членства в музичному товаристві в Берні, концертні програми 1960, 1961 років, які засвідчують участь в концертах, машинопис автобіографії на німецькій мові дружини Омеляна - Геді Нижанківської. До цієї групи документів належать афіші українських музикантів, в концертах яких звучали твори О. Нижанківського, а саме: «Вечір української пісні Любомира Мацюка».

Архів містить багаточисленні газетні вирізки про членів родини Нижанківських, машинописний матеріал про братів Мирона і Зенона Нижанківських, пакет матеріалів про Зенона Нижанківського (вирізки 3 газет, фото могили 3. Нижанківського на українськім кладовищі в Бавнбрук, Америка).

До другої групи належать авторські нотні рукописи Омеляна Нижанківського, а саме: три Служби Божі, текст дисертації «Історичносистематичне нашарування української народної пісні» та інше.

Третю групу становлять численні листи до відомих суспільногромадських та культурно-освітніх діячів. Митець вів кореспонденцію 3 апостольським візитатором єпископом-монсеньйором Мирославом Марусином, 3 дружиною полковника Свгена Коновальця, Ольгою Коновалець, дружиною полковника Андрія Мельника, Софією Мельник, 3 громадсько-політичним діячем, журналістом Михайлом Єреміївим, українським політичним діячем, публіцистом, одним із ідеологів Організації Українських Націоналістів Степаном Ленкавським, істориком, громадсько-політичним діячем, засновником видавництва «Дніпрова Хвиля» Олексою Вінтоняком, письменницею Ольгою Дучимінською, українською поетесою, перекладачем, мистецтвознавцем Мартою Калитовською, французьким та іспанським кінорежисером українського походження, активним діячем українського емігрантського руху Євгеном Деславом, українським педагогом, громадським діячем, дружиною Володимира Кубійовича Дарією Сіяк.

Серед численних епістолярних документів привертає увагу лист до «Українського Золотого Хреста» в Америці, гуманітарної секції при Організації державного відродження України, датований 30 травнем 1941 року. Відомо, що це громадське товариство підтримувало українську визвольну акцію на батьківщині, допомагало політичним 224 
в’язням і їх родинам на західно-українських землях, воєнним інвалідам i хворим учасникам визвольних змагань. У 1938-39 роках «Український Золотий Хрест» подавав матеріальну допомогу Карпатській Україні, а 3 1940 року відкрив своє представництво в Швейцарії (керівник О. Нижанківський) для допомоги українським полоненим й інтернованим за другої світової війни.

У листі мова йде про зірвані відвідини таборів для українських переселенців. Документ засвідчує, що митець фінансував подорож до них отця Мирослава Любачівського. О. Нижанківський також наголошує на виясненні загальної кількості інтернованих українців, які перебувають у таборах Швейцарії, задля конкретної допомоги їм у справі звільнення. Далі він зазначає, що профінансує перебування у таборах згаданого вже священика, курси мов та пересилку українських часописів. Лист є цінним історичним джерелом, котрий промовисто засвідчує різнопланову діяльність митця, вагомі миті складної історії перебування українців на чужині.

Частина епістолярію О. Нижанківського, що зберігається в архівних фондах Стрийського краєзнавчого музею «Верховина», $\epsilon$ переписка 3 Мирославом Марушином - єпископом Кадоенським, Апостольським візитатором українців в Західній Свропі. Це загалом святкові вітання.

Омелян Нижанківський вів активну переписку з музичними діячами: українським письменником, музикознавцем, джерелознавцем, автором «Словника співаків України» Іваном Лисенком, співачкою Іриною Маланюк, композитором Марком Брікюстом, польським митцем Ігнацієм Падеревським, українським піаністом, педагогом Романом Савицьким, українським співаком, хоровим диригентом і музикознавцем, доктором музикології Мирославом Антоновичем, українським диригентом та педагогом Богданом П'юрком, піаністом, професором Українського музичного інституту в Детройті Борисом Максимовичем, українським співаком Мирославом Скала-Старицьким, композитором, культурно-освітнім діячем Антіном Рудницьким.

Окрему групу становлять листи до дружини Геді НижанківськоїРінгер, зокрема від композитора, культурно-освітнього діяча Антіна Рудницького та інших.

Архів містить публікації Омеляна Нижанківського на музичні теми у пресі. Автор порушує питання про завдання українських музикантів, які перебувають на чужині.

Окремі документи - це запрошення на визначні суспільно-політичні події. Серед них привертає увагу запрошення на Перший світовий конгрес вільних українців, котрий відбувся 12-19 листопада 1967 року в Нью-Йорку. 
Цінною є газетна публікація Михайла Єремієва та Олександра Сірого «Лицар незламної волі» [4, с. 2; 4], присвячена відходу у засвіти Омеляна Нижанківського. Архівний документ $€$ вартісним джерелознавчим матеріалом щодо життєтворчості подвижника української культури.

Отож, подальше впорядкування та детальне вивчення архіву Омеляна Нижанківського дасть грунт для написання дослідження про життя та творчість відомого українського піаніста, педагога, громадського діяча зі Швейцарії. Багатий епістолярій, який потребує фахового перекладу на українську мову, висвітлить окремі сторінки з біографій визначних діячів української діаспори. Незаслужено забуте ім'я подвижника української культури Омеляна Нижанківського буде повернуте в науковий та мистецький обіг.

\section{Література:}

1. Антонович М. Між двома світовими війнами. Спогади. У двох частинах / Упор. і підготував до друку О. Долгий. Київ : ДП Поліграфіст, $2003.538 \mathrm{c}$.

2. Булка Ю. Нестор Нижанківський: Життя і творчість. Львів Нью-Йорк, 1997. 60 с.

3. Граб У. Професор Омелян Нижанківський (1895-1973). Украӥнська музика. 2013. № 4. С. 67-70.

4. Єреміїв М., Сірий О. Лицар незламної волі. Українське слово. 1973. 14 вересня. С. $2 ; 4$.

5. Карась Г. Музична культура української діаспори у світовому часопросторі XX століття. Івано-Франківськ: Тіповіт, 2012. 1164 с.

6. Кордуба 3. Северина Нижанківська. Галищька зоря. URL: https://hal-zoria.io.ua/s514950/severina_nijankivska. (дата звернення 20 листопада 2020).

7. Нижанківський Омелян. Мала украӥнська енциклопедія / упор. Осип Залеський. Мюнхен: Дніпрова хвиля, 1971. С. 80.

8. Рудницький А. Українська музика: історично-критичний огляд. Мюнхен: Дніпрова хвиля, 1968. 289 с. 